Finanse, Rynki Finansowe, Ubezpieczenia nr 3/2017 (87), cz. 2

DOI: $10.18276 /$ frfu.2017.87/2-02

s. $17-28$

\title{
Istota sprawiedliwości podatkowej pionowej i poziomej w kontekście liniowej oraz progresywnej stawki podatku dochodowego od osób fizycznych
}

\author{
Monika Pasternak-Malicka*
}

\begin{abstract}
Streszczenie: $\mathrm{Cel}$ - Celem artykułu jest wskazanie istoty sprawiedliwości podatkowej pionowej i poziomej w kontekście liniowej oraz progresywnej stawki opodatkowania dochodów osób fizycznych.

Metodologia badania - Realizacja celu wymagała wykorzystania metod opisowo-statystycznych, a w szczególności analizy koncepcji sprawiedliwości pionowej oraz poziomej w odniesieniu do stawki podatku dochodowego od osób fizycznych. Ponadto omówiono rozwiązania opodatkowania dochodów przyjęte w Polsce i wybranych krajach. Wykorzystano także metodę bezpośrednią - kwestionariuszową. W artykule posłużono się fragmentami własnych badań ankietowych z lat 2007-2017, w celu dokonania próby jakościowej oceny pionowej i poziomej sprawiedliwości podatkowej.

Wynik - Wyniki badania empirycznego przedsiębiorców oraz gospodarstw domowych także wydają się wskazywać na podatek progresywny jako bardziej odpowiadający sprawiedliwości podatkowej w odczuciu respondentów. Powszechna akceptacja progresji podatkowej wskazuje na silnie zakorzenione w polskim społeczeństwie poczucie sprawiedliwości pionowej, zgodnie z którym wyższe daniny powinni płacić bogatsi, zaś dochody osób mniej zamożnych należy opodatkować niższymi stawkami.

Oryginalność/wartość - Zasadniczą wartością artykułu jest analiza podatku dochodowego od osób fizycznych pod kątem sprawiedliwości pionowej i poziomej. Znamiona oryginalności nadają także prezentowane badania empiryczne przeprowadzone wśród gospodarstw domowych oraz podmiotów gospodarczych.
\end{abstract}

Słowa kluczowe: sprawiedliwość podatkowa, zasady podatkowe, sprawiedliwość pionowa i pozioma

\section{Wprowadzenie}

W literaturze przedmiotu przyjmuje się, że dobry system podatkowy powinien być tworzony zgodnie z zasadami podatkowymi, wśród których wyróżnia się także zasady sprawiedliwości podatkowej: równość, powszechność, zdolność podatkowa (dochodowa). Równocześnie sprawiedliwość jest pojęciem charakteryzującym się daleko idącą wieloznacznością i złożonością. Jego kształt jest często uzależniony od ideologii oraz światopoglądu wyznawanego przez osoby formułujące określoną koncepcję sprawiedliwości (Walz, 1980, s. 45). Z tego

* dr Monika Pasternak-Malicka, Politechnika Rzeszowska im. Ignacego Łukaszewicza, Zakład Finansów i Bankowości, e-mail: malicka@prz.edu.pl 
punktu widzenia zaobserwować można przeobrażenia w ujmowaniu postulatów sprawiedliwości podatkowej przez lata, a także jej zmiany wraz z pojawianiem się nowych nurtów w teorii ekonomii.

Prekursorem koncepcji sprawiedliwego kształtowania obowiązków podatkowych był Adam Smith, który sformułował zasadę równomierności opodatkowania (Smith, 2003, s. 584) ${ }^{1}$. Uznawany jest on za zwolennika stawki proporcjonalnej, podobnie jak David Ricardo, autor „,reguły edynburskiej” (Ricardo, 1957, s. 168) nawiązującej do idei neutralności systemu podatkowego. Za koncepcją podatku liniowego opowiadał się także John S. Mill twórca zasady równości ofiar (Mill, 1966, s. 564), który krytykował także progresywną formę opodatkowania, uznając wykorzystywanie danin jako narzędzia redystrybucji dochodu za niesprawiedliwe i szkodliwe ekonomicznie (Szczodrowski, 2002, s. 39). Odmiennie kwestię równomierności i sprawiedliwości opodatkowania rozumiał Jean Baptiste Say, będący zwolennikiem zastosowania w systemie podatkowym progresji (Sosnowski, 2012, s. 66). Także zdaniem Adolfa Wagnera musi być zachowana powszechność podatku i rozsądne progresywne opodatkowanie wysokich dochodów przy zachowaniu bodźca do osiągania zysku (Gomułowicz, Małecki, 2013, s. 63), natomiast za stosowaniem skal o silnej progresji opowiadał się Francis Ysidro Edgeworth. Podstawą takiej tezy było założenie, że krańcowa użyteczność dochodu każdej osoby jest jednakowa, wobec tego danina powinna być nakładana głównie na jednostki zamożne, gdyż ich utracone korzyści są mniejsze niż osób biednych (Owsiak, 2013, s. 190).

W literaturze przedmiotu występują dwie niezależne koncepcje sprawiedliwości w rozumieniu równości - sprawiedliwość pionowa i pozioma. W artykule podjęto problematykę sprawiedliwości pionowej i poziomej w odniesieniu do stawki podatkowej stosowanej w podatku dochodowych od osób fizycznych. Państwo za pomocą danin wpływa na rozmieszczenie zasobów w gospodarce, realizując funkcję redystrybucyjną finansów publicznych. Zastosowanie podatku progresywnego polegającego na wyższym obciążeniu daninami osób osiągających wyższe dochody, a następnie przekazanie części zgromadzonych środków osobom najuboższym realizuje jeden z postulatów sprawiedliwości. Równocześnie budzi kontrowersje zwolenników liniowego opodatkowania.

Celem artykułu jest wskazanie istoty sprawiedliwości podatkowej pionowej i poziomej w kontekście liniowej oraz progresywnej stawki opodatkowania dochodów osób fizycznych. W pierwszej części opisano teoretyczne podstawy koncepcji sprawiedliwości pionowej oraz poziomej. W następnym punkcie skoncentrowano się na rozwiązaniach opodatkowania dochodów osobistych w Polsce i wybranych krajach. W ostatniej części zaprezentowano fragmenty badań własnych z lat 2007-2017, prezentujące opinie respondentów na temat stawki podatkowej w odniesieniu do problemu sprawiedliwości w ujęciu pionowym oraz poziomym.

1 A. Smith nie używał pojęcia sprawiedliwość (equity) lecz równomierność (equality). 


\section{Sprawiedliwość pionowa oraz pozioma w odniesieniu do stawki liniowej i progresywnej}

W teorii ekonomii zagadnienie obiektywnej sprawiedliwości opodatkowania rozpatrywane jest w dwóch aspektach, a mianowicie sprawiedliwości poziomej i pionowej (Stiglitz, 2004, s. 565-567; Hall, Rabushka, 1998, s. 43; Gomułowicz, 2001, s. 27-28), określanych niekiedy jako sprawiedliwość wertykalna i horyzontalna (Kosek-Wojnar, 2012, s. 92-93). Sprawiedliwość pionowa oznacza odmienne traktowanie jednostek o różnych cechach, w celu zniwelowania istniejących między nimi dysproporcji. Koncepcja ta nawiązuje do sprawiedliwości dystrybutywnej Arystotelesa (inaczej rozdzielczej, lub według zasady ,jednemu mniej, drugiemu więcej”). Sprawiedliwość pozioma (redystrybutywna, wyrównawcza) przejawia się zaś w jednakowym traktowaniu osób charakteryzujących się takimi samymi cechami. Idea ta łączy się ściśle z zasadami równości oraz powszechności opodatkowania.

Przyjmuje się, że sprawiedliwość pozioma jest zazwyczaj akceptowana przez podatników. W kwestiach fiskalnych oznacza ona takie samo opodatkowanie jednostek, czyli zastosowanie podatku proporcjonalnego, w przypadku którego kwota daniny rośnie proporcjonalnie (liniowo) do wzrostu podstawy opodatkowania. Kontrowersje pojawiają się natomiast w związku ze sprawiedliwością pionową, która oznacza wyższe opodatkowanie jednostek lepiej usytuowanych oraz niskie obciążenia fiskalne nakładane na osoby ubogie, stanowiąc podstawę dla redystrybucji dochodów poprzez zastosowanie progresji podatkowej. Sprawiedliwość pionowa wyraża się w zróżnicowanej zdolności płatniczej.

W literaturze przedmiotu sprawiedliwość pionowa i pozioma jest najczęściej konkretyzowana za pomocą dwóch teorii podatkowych - teorii ekwiwalencji (benefit) oraz zdolności płatniczej (ability to pay) (Gail, 1992, s. 143; Gwiazdowski, 2007, s. 353). W teorii ekwiwalentności podatki są traktowane jako opłata za otrzymane od państwa świadczenia. Ponieważ w rzeczywistości, ze względu na rozbudowany system dóbr i usług publicznych, ocena korzyści, jakie podatnik otrzymuje od państwa jest niemożliwa do ustalenia, to teoria ekwiwalencji we współczesnej praktyce fiskalnej straciła na znaczeniu i została odrzucona (Gaudemet, Molinie, 2000, s. 430 i n.).

Teoria zdolności płatniczej zakłada natomiast niezależność świadczeń ze strony państwa i kwoty poniesionych obciążeń fiskalnych. Podatek rozumiany jest jako opłata nie za indywidualnie otrzymywane dobra i usługi, lecz za te zadania państwa, które służą ogólnemu dobru (Gomułowicz, 1995). Na gruncie tej doktryny racjonalizowane są zagadnienia sprawiedliwości przyjmujące, że w miarę wzrostu zdolności płatniczej dochód podatnika powinien być opodatkowany wyższą stawką. Wydaje się, że myśl ta jest bliższa idei podatku progresywnego.

Uwzględniając zasadę zdolności płatniczej, sprawiedliwość pionowa jest realizowana poprzez podatek progresywny z licznymi ulgami i zwolnieniami. W efekcie dokonywana jest redystrybucja dochodów, wskutek której niwelowane są nadmierne różnice w dochodach społeczeństwa. Z kolei sprawiedliwość pozioma odrzuca progresję w podatku dochodowym na rzecz opodatkowania proporcjonalnego, uznawanego za prostszy i dodatkowo równo traktujący podatników. Z uwagi na przeciwstawność tych dwóch koncepcji teoretycznych 
w praktyce przyjmuje się pogląd, że rozkład ciężaru podatkowego powinien odpowiadać poczuciu sprawiedliwości większości społeczeństwa.

Na poziomie mikroekonomicznym ocena sprawiedliwości jest subiektywna i zależna od uzyskiwania korzyści fiskalnych w wyniku stosowania poszczególnych instrumentów. Na poziomie makroekonomicznym dyskusja sprowadza się do nierozstrzygniętego sporu pomiędzy szkołą neoklasyczną a poglądami mieszczącymi się w nurcie keynesistowskim (Zbroińska, 2008, s. 92). Zgodnie z ujęciem neoklasycznym, czyli ideą wolności rynkowej, wiarą w mechanizm samoregulacji oraz ograniczania roli państwa, sprawiedliwy system podatkowy cechuje umiarkowane, proporcjonalne obciążenie wszystkich podatników (sprawiedliwość pozioma). Zwolennicy nurtu keynesistowskiego opowiadają się natomiast za aktywnością państwa w sterowaniu procesami gospodarczymi oraz zróżnicowaniem obciążeń fiskalnych stosownie do zdolności podatkowej (sprawiedliwość pionowa).

\section{Przyjęte rozwiązania opodatkowania osób fizycznych w Polsce i na świecie}

Pierwotnie, jak pokazuje historia, podatki były obliczane na zasadzie proporcjonalności. Z czasem (lata 30. XX w.) nabierały z zasady charakteru progresywnego (Brzeziński, 1995, s. 13). Systemy podatkowe obowiązujące obecnie w krajach europejskich ukształtowały się po II wojnie światowej. Na ich zmiany w dużym stopniu wpłynęła doktryna J.M. Keynesa odchodząca od idei neutralności podatków (sprawiedliwość pozioma) na rzecz funkcji pozafiskalnych oraz oparcia konstrukcji podatku dochodowego na zdolności dochodowej (sprawiedliwość pionowa).

W tabeli 1 zaprezentowano wysokość stawek podatkowych w wybranych krajach w latach 1975-2017. Wspólną cechą opodatkowania dochodów osobistych w państwach zachodniej i północnej Europy jest progresja podatkowa. Jej zastosowanie najczęściej uzasadnia się potrzebą uwzględnienia zdolności płatniczej oraz chęcią zmniejszenia dysproporcji w poziomie dochodów społeczeństwa, a tym samym realizowania zasady sprawiedliwości pionowej.

Początkowo podatek spełniający funkcję redystrybucyjną charakteryzował się wieloma ulgami i zwolnieniami oraz wysokimi maksymalnymi stawkami podatkowymi (sięgającymi, a nawet przekraczającymi 80\%). Znaczące obniżenie stawek PIT nastąpiło dopiero w pierwszej połowie lat 90. ubiegłego wieku. Uwarunkowania historyczne sprawiają, że wszystkie kraje tzw. starej UE nadal stosują progresywne opodatkowanie dochodów ludności, przy czym można zaobserwować tendencję do łagodzenia progresji przez spłaszczanie skali podatkowej (niwelowanie różnic pomiędzy maksymalną a minimalną stawką oraz ograniczanie liczby progów). W Polsce stosuje się także rozwiązania oparte na progresji, chociaż od 2004 roku osoby fizyczne prowadzące działalność gospodarczą mają możliwość wyboru stawki liniowej.

Nowe kraje UE oraz południowo-wschodniej Europy, które mają znacznie krótszą historię opodatkowania dochodów osobistych, częściej przyjmują rozwiązania oparte na formie 
liniowej (chociaż ze względu na występującą powszechnie kwotę wolną nadal pojawia się opodatkowanie malejące wraz z dochodem). Wyraźną tendencję do zmniejszania progresywności poprzez przechodzenie nowych krajów na system jednolitej stawki zaprezentowano w tabeli 2.

\section{Tabela 1}

Stawki podatku dochodowego w wybranych krajach UE w latach 1975-2017 (\%)

\begin{tabular}{|c|c|c|c|c|c|c|c|c|c|c|c|c|}
\hline \multirow{2}{*}{ Kraje } & \multicolumn{2}{|l|}{1975} & \multicolumn{2}{|l|}{1983} & \multicolumn{2}{|l|}{1989} & \multicolumn{2}{|l|}{1996} & \multicolumn{2}{|l|}{2000} & \multicolumn{2}{|l|}{2017} \\
\hline & $\min$ & $\max$ & $\min$ & $\max$ & $\min$ & $\max$ & $\min$ & $\max$ & $\min$ & $\max$ & $\min$ & $\max$ \\
\hline Francja & 5 & 60 & 5 & 65 & 5 & 57 & 10 & 54 & 9,5 & 54 & 8 & 45 \\
\hline Grecja & 3 & 66 & 11 & 63 & 18 & 50 & 5 & 45 & 5 & 45 & 10 & 45 \\
\hline Hiszpania & 15 & 62 & 25 & 60 & 25 & 65 & 17 & 47,6 & 15 & 39,6 & 9,5 & 22,5 \\
\hline Irlandia & 26 & 77 & 4 & 80 & 35 & 58 & 26 & 48 & 24 & 46 & 20 & 40 \\
\hline Portugalia & 4 & 80 & 22 & 56 & 16 & 40 & 15 & 40 & 14 & 40 & 14,5 & 48 \\
\hline Niemcy & 22 & 56 & 30 & 60 & 19 & 53 & 19 & 56 & 25 & 51 & 5,5 & 45 \\
\hline Polska & - & - & - & - & - & - & 21 & 45 & 19 & 40 & 18 & 32 \\
\hline $\begin{array}{l}\text { Wielka } \\
\text { Brytania }\end{array}$ & 35 & 83 & 30 & 60 & 25 & 40 & 20 & 40 & 10 & 40 & 20 & 45 \\
\hline Włochy & 10 & 72 & 18 & 68 & 10 & 50 & 10 & 51 & 18,5 & 45,5 & 23 & 43 \\
\hline
\end{tabular}

Źródło: opracowanie własne na podstawie: Krajewska (2012, s. 95); status.oecd.org/index.aspx.

\section{Tabela 2}

Stawki podatkowe w wybranych krajach, które wprowadziły podatek liniowy (\%)

\begin{tabular}{lllll}
\hline Kraj & $\begin{array}{l}\text { Rok } \\
\text { wprowadzenia }\end{array}$ & $\begin{array}{l}\text { Progresywne stawki (w roku } \\
\text { poprzedzającym wprowadzenie } \\
\text { podatku liniowego) }\end{array}$ & $\begin{array}{l}\text { Liniowa (w roku } \\
\text { wprowadzenia) }\end{array}$ & $\begin{array}{l}\text { Aktualnie } \\
\text { obowiązujące }\end{array}$ \\
\hline Białoruś & 2008 & 9,30 & 12 & 12 \\
\hline Bułgaria & 2008 & $20,22,24$ & 10 & 10 \\
\hline Czechy & 2008 & $12,19,25,32$ & 15 & 15 \\
\hline Estonia & 1994 & 16,33 & 26 & 15 \\
\hline Litwa & 1994 & $25,35,45,50$ & 33 & 23 \\
\hline Łotwa & 1994 & 25,35 & 25 & 13 \\
\hline Rosja & 2001 & $12,20,30$ & 13 & 16 \\
\hline Rumunia & 2005 & $18,23,28,34,40$ & 16 & 18 i 25 \\
\hline Słowacja* & 2004 & $10,20,28,35,38$ & 19 & 15 \\
\hline Ukraina & 2004 & $10,15,20,30,40$ & 15 & 16 \\
\hline Węgry & 2011 & 18,36 & 15 & 15 \\
\hline
\end{tabular}

* Od 2013 r. Słowacja zniosła podatek liniowy i wprowadziła progresywny.

** Stawka podstawowa w 2017 r. wynosi 18\%, ale występują też obniżone - 0\% oraz 5\%.

Źródło: opracowanie własne na podstawie: Krajewska (2012, s. 102-103); status.oecd.org/index.aspx. 
W krajach, które jako pierwsze wprowadziły podatek liniowy (Estonia, Litwa. Łotwa) i jednocześnie ustaliły stawkę na stosunkowo wysokim poziomie, można zauważyć tendencję do stopniowego obniżania wysokości opodatkowania. Słowacja jako jedyna zrezygnowała z rozwiązania liniowego na rzecz powrotu do progresji. Obecnie najniższe stawki podatku proporcjonalnego (10\%) obowiązują w Serbii, Macedonii, Albanii, Czarnogórze oraz Bułgarii.

\section{Forma opodatkowania w świetle badań empirycznych}

W tej części publikacji zaprezentowano wyniki badań ankietowych, które zawierają opinie respondentów na temat sprawiedliwości podatkowej w odniesieniu do progresywnej oraz liniowej stawki opodatkowania dochodów osobistych. Badania własne ${ }^{2}$ wskazują, że nie istnieje jednomyślność poglądów wśród ankietowanych osób na temat formy, jaką powinna charakteryzować się sprawiedliwa stawka podatku obciążająca dochód gospodarstw domowych. W badanym dziesięcioletnim okresie (2007-2017) zaobserwowano znaczną przewagę zwolenników progresywnej stawki podatku (tab. 3). Wyjątek stanowił jedynie 2007 rok, kiedy ponad połowa osób udzielających odpowiedzi opowiedziała się za opcją liniową, natomiast 46,4\% respondentów wybrała opcję stawki progresywnej z różną liczbą progów.

W kwestii liczby szczebli opodatkowania też nie odnotowano jednomyślności w opinii ankietowanych. Blisko co trzecia osoba opowiadała się za stawką liniową, spełniającą postulaty sprawiedliwości poziomej, natomiast wśród zwolenników progresji w latach 2009-2012 było niemal tyle samo osób popierających rozwiązanie z dwoma, co i z trzema stawkami.

2 Badania własne przeprowadzono na celowej próbie 686 gospodarstw domowych oraz 219 podmiotów gospodarczych (w maju 2007 roku), 750 gospodarstw domowych i 250 podmiotów (w maju 2009 roku), 1084 gospodarstw domowych oraz 250 podmiotów (w kwietniu i maju 2010 roku), 1201 gospodarstw domowych oraz 281 podmiotów (w maju 2011 roku), 1230 gospodarstw domowych oraz 232 podmiotów (w styczniu 2012 roku), 1128 gospodarstw domowych oraz 237 podmiotów (w styczniu 2013 roku), 857 gospodarstw domowych oraz 188 podmiotów (w styczniu 2014 roku), 852 gospodarstw domowych oraz 244 podmiotów (w styczniu 2015 roku), 1103 gospodarstw domowych oraz 325 podmiotów (w styczniu 2016 roku) oraz 1038 gospodarstw domowych (w styczniu 2017 roku). Jest to kontynuacja badań ankietowych zapoczątkowana w maju 2007 roku i powtarzana rokrocznie. W badaniach ankietowych przeprowadzonych w maju 2007 roku wzięły udział gospodarstwa domowe oraz podmioty gospodarcze z terenu całej Polski, natomiast wywiady w latach 2009-2017 zostały przeprowadzone na terenie województwa podkarpackiego. Ankiety były skierowane do osób powyżej 20. roku życia o zróżnicowanym poziomie dochodów oraz standardzie życia. Natomiast kwestionariusze dla przedsiębiorców dotyczyły podmiotów z sektora MSP o zróżnicowanym poziomie obrotów, liczbie zatrudnionych pracowników oraz okresie funkcjonowania na rynku. 


\section{Tabela 3}

Struktura odpowiedzi na pytanie: W jaki sposób powinny być opodatkowane dochody ludności?

\begin{tabular}{|c|c|c|c|c|c|c|c|c|c|c|}
\hline \multirow{2}{*}{$\begin{array}{l}\text { Sposób opodatkowania } \\
\text { dochodów ludności }\end{array}$} & \multicolumn{10}{|c|}{ Struktura procentowa } \\
\hline & 2007 & 2009 & 2010 & 2011 & 2012 & 2013 & 2014 & 2015 & 2016 & 2017 \\
\hline podatkiem liniowym & 50,9 & 31,1 & 29,7 & 27,7 & 26,3 & 25,7 & 23,2 & 32,4 & 24,3 & 35,0 \\
\hline $\begin{array}{l}\text { podatkiem } \\
\text { progresywnym } \\
\text { z dwoma stawkami }\end{array}$ & 18,4 & 22,0 & 21,9 & 23,1 & 22,5 & 31,5 & 26,6 & 29,2 & 29,4 & 27,2 \\
\hline $\begin{array}{l}\text { podatkiem } \\
\text { progresywnym z trzema } \\
\text { stawkami }\end{array}$ & 10,1 & 21,1 & 22,6 & 25,0 & 23,3 & 19,5 & 25,7 & 18,9 & 25,0 & 18,9 \\
\hline $\begin{array}{l}\text { podatkiem } \\
\text { progresywnym } \\
\text { z większą liczbą stawek }\end{array}$ & 17,9 & 22,3 & 23,2 & 22,8 & 25,6 & 21,6 & 23,6 & 18,2 & 18,2 & 16,4 \\
\hline inny wariant & 1,6 & 0,9 & 0,9 & 0,8 & 1,1 & 0,8 & 0,7 & 1,2 & 1,6 & 1,9 \\
\hline brak odpowiedzi & 1,2 & 2,7 & 1,8 & 0,7 & 1,2 & 0,9 & 0,2 & 0,1 & 1,1 & 0,7 \\
\hline
\end{tabular}

Źródło: obliczenia własne na podstawie danych z przeprowadzonych badań ankietowych w latach 2007-2017.

W tabeli 4 przedstawiono strukturę procentową odpowiedzi na pytanie o najbardziej sprawiedliwą formę opodatkowania dochodów osobistych w zależności od płci, wieku, poziomu dochodów, wykształcenia czy obowiązujących daną osobę stawek podatku, zgodnie z którymi rozlicza ona swoje dochody.

W każdej grupie wiekowej stawka progresywna zyskiwała większe poparcie wśród osób biorących udział w badaniu, chociaż najmłodsi i najstarsi uczestnicy badania wykazywali największe poparcie dla formy liniowej. Osoby wskazujące progresję wybierały najczęściej wariant z dwoma stawkami, czyli obecnie obowiązujący w polskim systemie podatkowym (od 23,2\% w grupie najmłodszej, do 32,6\% w przedziale wiekowym 51-60 lat). Kobiety nieznacznie bardziej wydają się być zwolenniczkami progresji (33,5\% kobiet w porównaniu z 37,7\% mężczyzn wskazało na liniowość), natomiast opcję progresywną z dwoma stawkami wybrało 30,6\% kobiet, a jedynie 23,2\% mężczyzn. W przypadku innych wariantów różnice nie były już tak zauważalne.

Nie zaskakuje, że osoby osiągające wyższe dochody częściej opowiadały się za liniową formą opodatkowania PIT, natomiast respondenci mniej zamożni - za progresją. Podobnie osoby prowadzące działalność gospodarczą oraz pracujące dorywczo najczęściej wskazywały na liniową formę opodatkowania (blisko 40\%). 


\section{Monika Pasternak-Malicka}

\section{Tabela 4}

Struktura odpowiedzi na pytanie o stawkę podatkową w kontekście sprawiedliwości a cechy respondentów

\begin{tabular}{|c|c|c|c|c|c|c|}
\hline \multirow[b]{2}{*}{$\begin{array}{l}\text { Cechy respondentów } \\
\text { Wiek }\end{array}$} & \multicolumn{6}{|c|}{ Opinia dotycząca rodzaju stawki podatku (\%) } \\
\hline & liniowa & $\begin{array}{l}\text { progresywna } \\
\text { z dwoma } \\
\text { stawkami }\end{array}$ & $\begin{array}{l}\text { progresywna } \\
\text { z trzema } \\
\text { stawkami }\end{array}$ & $\begin{array}{l}\text { progresywna } \\
\text { z większą } \\
\text { liczbą stawek }\end{array}$ & $\begin{array}{l}\text { inny } \\
\text { wariant }\end{array}$ & $\begin{array}{l}\text { razem } \\
\text { (liczba } \\
\text { osób) }\end{array}$ \\
\hline poniżej 25 lat & 37,6 & 23,2 & 18,8 & 19,2 & 1,2 & 250 \\
\hline $26-35$ lat & 29,9 & 29,4 & 20,9 & 18,0 & 1,9 & 211 \\
\hline $36-50$ lat & 36,0 & 26,4 & 17,6 & 16,0 & 3,6 & 250 \\
\hline $51-60$ lat & 34,8 & 32,6 & 19,1 & 12,9 & 0,6 & 178 \\
\hline powyżej 60 lat & 38,3 & 27,0 & 19,2 & 14,2 & 1,4 & 141 \\
\hline \multicolumn{7}{|l|}{ PŁEĆ } \\
\hline kobieta & 33,5 & 30,6 & 17,8 & 16,2 & 1,9 & 585 \\
\hline mężczyzna & 37,7 & 23,2 & 20,0 & 17,1 & 1,8 & 440 \\
\hline \multicolumn{7}{|l|}{ ŹRÓDŁO UTRZYMANIA } \\
\hline stypendium + praca dorywcza & 40,1 & 24,7 & 17,6 & 17,0 & 0,6 & 182 \\
\hline pracownik sektora publicznego & 38,2 & 28,9 & 17,3 & 13,9 & 1,7 & 173 \\
\hline pracownik sektora prywatnego & 32,3 & 29,1 & 18,5 & 19,2 & 1,9 & 260 \\
\hline $\begin{array}{l}\text { samodz. działalność } \\
\text { gospodarcz }\end{array}$ & 40,3 & 21,0 & 21,0 & 16,1 & 1,7 & 62 \\
\hline wolny zawód & 33,3 & 25,0 & 25,0 & 16,7 & 0 & 60 \\
\hline emeryt lub rencista & 35,7 & 29,9 & 21,2 & 11,5 & 1,3 & 157 \\
\hline bezrobotny & 32,8 & 25,0 & 17,2 & 23,4 & 1,6 & 64 \\
\hline \multicolumn{7}{|l|}{ WYKSZTALCENIE } \\
\hline podstawowe & 49,3 & 18,8 & 14,5 & 14,5 & 2,9 & 69 \\
\hline zasadnicze zawodowe & 33,6 & 27,9 & 22,1 & 14,8 & 1,6 & 244 \\
\hline średnie i pomaturalne & 33,2 & 28,4 & 19,2 & 17,7 & 1,5 & 476 \\
\hline wyższe & 37,5 & 27,7 & 16,2 & 16,6 & 2,1 & 235 \\
\hline \multicolumn{7}{|l|}{ DOCHODY per capita } \\
\hline do $600 \mathrm{zl}$ & 31,7 & 30,2 & 20,1 & 16,6 & 1,5 & 199 \\
\hline $601-1000 \mathrm{zl}$ & 36,4 & 26,7 & 18,7 & 17,4 & 0,8 & 363 \\
\hline $1001-2000 \mathrm{zl}$ & 35,6 & 27,3 & 19,3 & 14,9 & 2,9 & 348 \\
\hline powyżej $2000 \mathrm{zl}$ & 37,1 & 25,9 & 15,5 & 18,1 & 2,6 & 116 \\
\hline \multicolumn{7}{|l|}{ PRÓG PODATKOWY } \\
\hline $18 \%$ (I próg) & 36,1 & 27,6 & 18,7 & 16,1 & 1,6 & 638 \\
\hline $32 \%$ (II próg) & 31,7 & 14,6 & 31,7 & 14,6 & 4,9 & 41 \\
\hline $\begin{array}{l}\text { rozliczam się na innych } \\
\text { zasadach }\end{array}$ & 32,7 & 28,3 & 19,5 & 15,0 & 4,4 & 113 \\
\hline nie rozliczam się w ogóle & 35,0 & 28,3 & 16,6 & 19,3 & 0,9 & 223 \\
\hline
\end{tabular}

Źródło: obliczenia własne na podstawie danych z przeprowadzonych badań ankietowych w styczniu 2017.

Ankietowani rozliczający się według 32-procentowej stawki ponad dwukrotnie częściej wybierali liniowość (odpowiednio: 31,7\% oraz 14,6\%). Zaskakujące jest jednak relatywnie 
wysokie poparcie dla stawki liniowej wśród osób z pierwszego progu podatkowego $(36,1 \%)$, co może być podyktowane kreatywnym wykorzystaniem przepisów podatkowych umożliwiających obniżenie podstawy opodatkowania również wśród osób osiągających wysokie dochody, przez co większe w tej grupie poparcie proporcjonalności.

\section{Tabela 5}

Struktura odpowiedzi na pytanie: Jaki system podatkowy bylby sprawiedliwy wedlug Pana/i?

\begin{tabular}{|c|c|c|c|c|c|c|c|c|c|c|}
\hline \multirow{2}{*}{$\begin{array}{l}\text { Sprawiedliwy system } \\
\text { podatkowy }\end{array}$} & \multicolumn{10}{|c|}{ Struktura odpowiedzi (\%) } \\
\hline & 2007 & 2009 & 2010 & 2011 & 2012 & 2013 & 2014 & 2015 & 2016 & 2017 \\
\hline bez ulg i zwolnień & 16,6 & 9,8 & 9,6 & 11,0 & 9,9 & 9,3 & 12,2 & 6,6 & 9,8 & 7,3 \\
\hline z większą liczbą ulg i zwolnień & 23,6 & 29,4 & 42,4 & 32,4 & 33,6 & 35,0 & 29,8 & 33,2 & 38,5 & 25,6 \\
\hline $\begin{array}{l}\text { jedna stawka podatku } \\
\text { dochodowego dla wszystkich }\end{array}$ & 25,6 & 18,2 & 20,4 & 17,1 & 12,1 & 11,0 & 20,8 & 17,7 & 11,1 & 19,7 \\
\hline $\begin{array}{l}\text { z jedną stawką podatkową } \\
\text { VAT }\end{array}$ & 17,6 & 10,0 & 16,8 & 14,0 & 16,9 & 6,3 & 15,4 & 14,8 & 11,7 & 14,2 \\
\hline $\begin{array}{l}\text { z niższymi podatkami } \\
\text { dochodowymi }\end{array}$ & 45,2 & 35,0 & 36,8 & 29,9 & 40,6 & 24,5 & 45,7 & 40,2 & 36,0 & 41,2 \\
\hline $\begin{array}{l}\text { z niższymi podatkami } \\
\text { pośrednimi }\end{array}$ & 28,1 & 20,1 & 20,4 & 14,0 & 22,8 & 13,5 & 25,5 & 28,7 & 26,5 & 26,3 \\
\hline inne & 1,0 & 0,4 & 0,4 & 1,1 & 1,3 & 0 & 0 & 0 & 0,6 & 1,7 \\
\hline RAZEM* & 157,0 & 125,3 & 147,2 & 129,1 & 140,2 & 100,0 & 149,5 & 141,2 & 134,0 & 136,0 \\
\hline brak odpowiedzi & 0 & 2,4 & 0,4 & 9,6 & 3,0 & 0,4 & 0 & 0 & 0,3 & 0 \\
\hline
\end{tabular}

*Suma wynosi ponad 100\%, gdyż ankietowani mogli wskazać wiele odpowiedzi.

Źródło: obliczenia własne na podstawie danych z przeprowadzonych badań ankietowych w latach 2007-2017 wśród podmiotów gospodarczych.

W tabeli 5 przedstawiono opinie przedsiębiorców na temat cech, jakimi powinien charakteryzować się sprawiedliwy system podatkowy. Za formą opodatkowania odpowiadającą koncepcji sprawiedliwości poziomej, czyli stawką liniową, opowiedziało się blisko 20\% przedsiębiorców. Najczęściej wskazywano ten wariant odpowiedzi w 2007 roku (co czwarty ankietowany), natomiast najmniejsze poparcie dla tej stawki odnotowano w 2013 oraz 2016 roku (jedynie co dziesiąty przedsiębiorca uważał tę formę za sprawiedliwą).

Uwzględniając zasadę zdolności płatniczej, sprawiedliwość pionowa realizowana jest poprzez progresywny podatek z licznymi ulgami i zwolnieniami. Tak skonstruowany system podatkowy pozwala na niwelowanie nadmiernych różnic w dochodach społeczeństwa. Za dokonywaniem redystrybucji dochodów, poprzez zwiększenie katalogu ulg i zwolnień, opowiedział się blisko co trzeci przedstawiciel podmiotów gospodarczych. Najmniej wskazań zaobserwowano w 2007 roku - 23,6\%, najwięcej w 2009 roku - 42,4\%. 


\section{Uwagi końcowe}

Problematyka podatku dochodowego od osób fizycznych jest nadal jednym z problemów wzbudzających kontrowersje, gdyż zdania specjalistów są podzielone. Wśród kwestii wywołujących spory i dyskusje wymienić należy rozważania dotyczące upraszczania systemu podatkowego w zakresie zastosowania proporcjonalnych stawek podatkowych. W krajach Unii Europejskiej stosuje się różne rozwiązania dotyczące podatku dochodowego od osób fizycznych. W większości przypadków podatnicy rozliczają się według progresywnej skali podatkowej. Równocześnie przybywa państw stosujących liniową formę opodatkowania dochodów osobistych. Trudno jest jednoznacznie określić, które rozwiązanie jest bardziej sprawiedliwe.

W literaturze przedmiotu wyodrębnia się sprawiedliwość poziomą i pionową. Propagatorzy sprawiedliwości poziomej odrzucają progresję w podatku dochodowym, uważając ją za niesprawiedliwą. Ich zdaniem podatek progresywny nie przyczynia się także do równomiernego rozłożenia ciężaru podatkowego w społeczeństwie. Wynika to głównie z tego, że w podatku tym występują ulgi i zwolnienia, które są wykorzystywane przez najbogatszych do unikania daniny. Ponadto progresja zniechęca do osiągania wyższych dochodów, przez co przyczynia się do uchylania od płacenia podatków, natomiast silna progresja podatkowa jest wyrazem realizowania zasady sprawiedliwości pionowej.

Sprawiedliwość pionową oraz poziomą można postrzegać jako sprawiedliwość obiektywną, natomiast przedstawione przez ankietowanych poglądy stanowić będą sprawiedliwość podatkową w ujęciu subiektywnym. W publikacji za ujęcie subiektywne przyjęto indywidualną (subiektywną) ocenę podatków pod kątem zasad sprawiedliwości podatkowej, ze szczególnym uwzględnieniem dylematu dotyczącego formy liniowej bądź progresywnej opodatkowania.

Badania ankietowe wskazują, że przeważają zwolennicy sprawiedliwości pionowej, opartej na zasadzie zdolności podatkowej. W dziesięcioletnim okresie badania udział entuzjastów progresji (z różną liczbą stawek) wahał się pomiędzy 60\% a 70\% respondentów. Wyniki badania empirycznego przedsiębiorców także wydają się wskazywać na podatek progresywny jako bardziej odpowiadający sprawiedliwości podatkowej w odczuciu respondentów. Powszechna akceptacja progresji wskazuje na silnie zakorzenione w polskim społeczeństwie poczucie sprawiedliwości pionowej, zgodnie z którym wyższe daniny powinni płacić bogatsi, zaś dochody osób mniej zamożnych należy opodatkować niższymi stawkami.

Problem sprawiedliwości w opodatkowaniu, pojawiający się jako postulat etyczny zyskuje na znaczeniu i systematycznie koncentruje uwagę twórców systemu podatkowego. W normach sprawiedliwości szuka się obiektywnego kryterium usprawiedliwiającego konieczność nakładania podatków. Wydaje się jednak, że osiągnięcie sprawiedliwości podatkowej nie jest łatwe, wręcz niemożliwe, gdyż zawsze stanowić będzie konflikt pomiędzy interesami podatnika a państwa. 


\section{Literatura}

Brzeziński, B. (1995). Prawo podatkowe. Toruń: Tonik „Dom Organizatora”.

Gail, N. (1992). Teorie podatkowe w świecie. Warszawa: PWN.

Gaudemet, P., Molinie, J. (2000). Finanse publiczne. Warszawa: PWE.

Gomułowicz, A., Małecki, J. (2013). Podatki i prawo podatkowe. Warszawa: LexisNexis.

Gomułowicz, A. (1995). Postulat sprawiedliwości a system podatkowy. Monitor Podatkowy, 4.

Gomułowicz, A. (2001). Zasada sprawiedliwości podatkowej. Kontrowersje podatkowe. Warszawa: Dom Wydawniczy ABC.

Gwiazdowski, R. (2007). Podatek progresywny i proporcjonalny. Doktrynalne przesłanki, praktyczne konsekwencje. Warszawa: Wydawnictwo Uniwersytet Warszawski.

Hall, R.E., Rabushka, A. (1998). Podatek liniowy. Warszawa: Dom Wydawniczy ABC.

Kosek-Wojnar, M. (2012). Zasady podatkowe w teorii i praktyce. Warszawa: Polskie Wydawnictwo Ekonomiczne.

Krajewska, A. (2012). Podatki w Unii Europejskiej. Warszawa: PWE.

Mill, J.S. (1966). Zasady ekonomii politycznej, t. 2. Warszawa: PWN.

Owsiak, S. (2013). Finanse publiczne. Teoria i praktyka. Warszawa: Wydawnictwo Naukowe PWN.

Ricardo, D. (1957). Zasady ekonomii politycznej i opodatkowania. Warszawa: PWN.

Smith, A. (2003). Badania nad natura i przyczynami bogactwa narodów. Warszawa: Wydawnictwo Naukowe PWN.

Sosnowski, M. (2012). Znaczenie zasad podatkowych dla systemu podatkowego. Zeszyty Naukowe Uniwersytetu Szczecińskiego, 708. Finanse, Rynki Finansowe, Ubezpieczenia, 52, 66.

Stiglitz, J.E. (2004). Ekonomia sektora publicznego. Warszawa: Wydawnictwo Naukowe PWN.

Szczodrowski, G. (2002). Polski system podatkowy. Strategia transformacji. Gdańsk: Wydawnictwo Uniwersytetu Gdańskiego.

Walz, W.R. (1980). Steuergerechtigkeit und Rechtsanwendung. Grundlinien einer relativ autonomen Steuerrechtsdogmatik. Hamburg: Heidelberg.

Zbroińska, B. (2008). Pozafiskalne funkcje podatku dochodowego w praktyce gospodarczej. Gospodarka Narodowa, 1-2, 92. 


\title{
SIGNIFICANCE OF VERTICAL AND HORIZONTAL JUSTICE IN THE LINEAR CONTEXT AND PROGRESSIVE RATE OF PROFESSIONAL TAX FROM PHYSICAL PERSONS
}

\begin{abstract}
Summary: Purpose - The purpose of this article is to show the essence of the vertical and horizontal tax justice in the context of the linear and progressive rate of taxation of individual income. Study Methodology - To achieve the objective of this article implementation of descriptive methods was required, in particular, the analysis of the concept of vertical and horizontal justice in relation to the rate of personal income tax. In addition, the forms of personal income taxations was discussed adopted by Poland and other selected countries. A direct method was also used - questionnaires. In this article fragments of self-conducted study were quoted, from the years 2007-2017, to make a qualitative attempt to assess vertical and horizontal tax justice.

Results - The results of the empirical study conducted on entrepreneurs and households appear to indicate that progressive tax system is more responsive to tax justice in respondents' perceptions. The widespread acceptance of progress taxation indicates a strong sense of vertical justice in the Polish society, according to which higher taxes should be paid by the by the wealthier, and the income of the less prosperous should be taxed at a lower rate.

Originality/value - The fundamental value of this publication is the analysis of personal income tax for vertical and horizontal justice. The originality is presented thanks empirical research conducted among economic entities and households.
\end{abstract}

Keywords: tax justice, tax rules, vertical and horizontal justice

\section{Cytowanie}

Pasternak-Malicka, M. (2017). Istota sprawiedliwości podatkowej pionowej i poziomej w kontekście liniowej oraz progresywnej stawki podatku dochodowego od osób fizycznych. Finanse, Rynki Finansowe, Ubezpieczenia, 3 (87/2), 17-28. DOI: 10.18276/frfu.2017.87/2-02. 